Article

\title{
A New Preparation Method of Microfauna from Gypsum: Micropaleontological Association from the Middle Miocene Badenian Gypsum Deposits of Paratethys
}

\author{
Hans-Peter Bojar ${ }^{1}$, Claudia Antoniade ${ }^{2}$, Victor Barbu ${ }^{3}\left[\right.$ and Ana-Voica Bojar ${ }^{1,4,5, *}$ (D) \\ 1 Studienzentrum Naturkunde-Mineralogie, Universalmuseum Joanneum, Weinzöttlstraße 16, \\ 8045 Graz, Austria; hans-peter.bojar@museum-joanneum.at \\ 2 OMV Petrom, Research and Design Institute of Technology Petrom Câmpina, Culturii Bldv 29, Câmpina, \\ 15600 Prahova, Romania; claudia.antoniade@gmail.com \\ 3 OMV Petrom, Coralilor str. 22, 013329 Bucharest, Romania; barbu.victor@gmail.com \\ 4 Department Geographie und Geologie, Geologie, University of Salzburg, Hellbrunnerstraße 34, \\ 5020 Salzburg, Austria \\ 5 Faculty of Physics, Department of Structure of Matter, Earth and Atmospheric Physics and Astrophysics, \\ University of Bucharest, Bulevardul Regina Elisabeta 4-12, 030018 Bucharest, Romania \\ * Correspondence: ana-voica.bojar@sbg.ac.at
}

Received: 23 March 2020; Accepted: 26 April 2020; Published: 28 April 2020

check for updates

\begin{abstract}
Evaporitic gypsum deposits represent an important paleoenvironmental record of the Miocene Badenian of the Carpathian Mountains belt. In this study, we developed a nontoxic method to concentrate calcareous microfossils from gypsum $\left(\mathrm{CaSO}_{4} \cdot 2 \mathrm{H}_{2} \mathrm{O}\right)$, by treating the sulfate with ammonium acetate. We applied the newly developed method to gypsum collected from the Evaporitic Formation outcropping northward of Slănic-Prahova in the Eastern Carpathians. For the first time for this formation, we describe a calcareous microfossil assemblage characterized by the presence of planktonic foraminifera as well as cysts and fragments of calcareous algae.
\end{abstract}

Keywords: chemical preparation method; gypsum deposits; calcareous microfossil assemblage; Miocene; Eastern Carpathians

\section{Introduction}

In the Earth's history, sulfate rich marine waters are known for late Precambrian (Vendian), Pennsylvanian-Triassic, Miocene to Quaternary [1]. The formed evaporitic deposits represent important archives, their formation indicating particular depositional environment and climatic conditions.

Microfossils in gypsum are important in order to investigate the ecology of organisms and their limit to tolerate high salinities. Microfossils are also excellent paleoenvironmental indicators, offering a unique opportunity in order to gain environmental information at the time of evaporite formation. Microfossils in marls and clay-rich rocks are concentrated by classical methods as mechanical crushing, sieving and hand picking. If the host rock is evaporitic and rich in sulfates as gypsum, the abundance of microfossils is low and it is challenging to gain substantial fossil material. Hydrogen peroxide $\mathrm{H}_{2} \mathrm{O}_{2}$ dissolves organic material and disaggregates particles but it does not affect sulfates. Due to the solubility of Ca-carbonate at low $\mathrm{pH}$, a preparation with acids is not suitable. In this study, we developed a non-toxic, cheap method for extraction of microfossils from gypsum $\mathrm{CaSO}_{4} \cdot 2 \mathrm{H}_{2} \mathrm{O}$ formed during evaporation when sea water salinity increases until saturation causes mineral deposition. We tested the newly developed method on massive gypsum boulders of the Middle Miocene (Badenian) 
Evaporitic Formation, Eastern Carpathians and, for the first time, we describe a microfossil assemblage belonging to this formation.

\section{Geological Setting}

The Green Stone Hill (Muntele Piatra Verde) is situated in the northern part of the Slănic-Prahova locality, where one of the biggest salt mines from Romania is situated (Figure 1A). Here, at the Green Stone Hill, the following formations are outcropping: (a) Slănic Formation with "Globigerina Marls" followed by Slănic Tuff (main green color). Within the Slănic green tuff, discrete layers of gypsum and white tuffs [2], rich in biotite, occur (Figure 1C); (b) The Evaporitic Formation, with salt breccias, gypsum as continuous layers or lenses and salt accumulation [3]. (c) The Radiolarian Shales Formation, rich in radiolarians such as: Coenosphaera, Dictyocoryne, Halicapsa, Rhopalodictyum, Sethocapsa and Spongodiscus [4]; (d) The Spirialis Marl Formation. The stratigraphic age of the section is indicated by the association Orbulina suturalis and Globorotalia bykovae (Upper Langhian-Moravian), Globoturborotalita druryi and Globorotalia transsylvanica (terminal part of Upper Langhian-Lower Serravalian-Wielician) and Velapertina (Lower Serravallian-Kossovian) Zones [5,6].

The lower part of the Slănic Formation ("Globigerina marls") contains mainly planktonic foraminifera: Praeorbulina spp., Orbulina suturalis, Globigerinoides spp., Globorotalia bykovae, G. praescitula, Paragloborotalia mayeri, Globoturborotalita woodi, Globigerina bulloides, Globigerinella obesa, etc. This is assigned to the Orbulina suturalis/Globorotalia bykovae Zone $[5,7,8]$.

The uppermost part of the Slănic Formation is rich in foraminifera indicating a cooler water assemblage (Globigerina bulloides, G. concinna, Globigerinita uvula, etc.). Unlike the lower part of the Slănic Formation, almost devoid of benthonic foraminifera, this interval shows a rich typical Wielician type association with Pseudotriplasia minuta, Uvigerina orbignyana, Glandulina laevigata, Sphaeroidina bulloides, Melonis pompilioides, etc. [5,9,10].

For the Evaporitic Formation, no foraminifera or calcareous nanoplankton assemblages were published so far. The formation consists of salt breccias, gypsum and halite accumulations. Based on nannoplankton association, the age of the deposits below this formation belongs to NN6 Zone (CNZ) [11], but no microfossils have been directly described from the gypsum strata. From the thin clayey beds within the gypsum, few molluscs were found: Pycnodonta, Ostrea, Glycimeris, Chlamys, Diloma, Callistoma and Vernetus genera [12]. Radiometric data on two different tuff levels, situated under- and on the top of the evaporitic formation, determine the interval of evaporites deposition. The tuff below the Evaporitic Formation was dated by [2], indicating deposition after the dated tuff at $13.7 \pm 0.7 \mathrm{Ma}$. The tuff dated on the top of the Evaporitic Formation indicated an age of $13.45 \pm 0.06 \mathrm{Ma}$ [13], a tuff age that was readjusted later on to $13.32 \pm 0.07 \mathrm{Ma}$ [14]. The ages were reported to Central Paratethys regional stages, which are correlated in Figure 1 to the Mediterranean regional stages.

The Evaporitic Formation is covered by the Radiolarian Shales containing the foraminifera association: Globorotalia transsylvanica, G. bykovae, Paragloborotalia mayeri, Globigerinoides triloba, Globigerina bulloides, Praeorbulina glomerosa, P. sicana, Orbulina suturalis, Globoturborotalita woodi, G. druryi, Globigerina cf. tarchanensis. The shales are assigned to Globoturborotalita druryi/Globorotalia transsylvanica Zone. The calcareous nannofossil association indicates the presence of NN6 CNZ [11] (Figure 1C). The uppermost occurring formation, the Spirialis Formation belongs to the NN6 CNZ [15]. The foraminifera association contains different species of Velapertina (e.g., V. indigena, V. luczkowskae) and indicated the presence of the Kossovian substage (upper part of Late Badenian, Velapertina Zone $[5,6]$ ). 


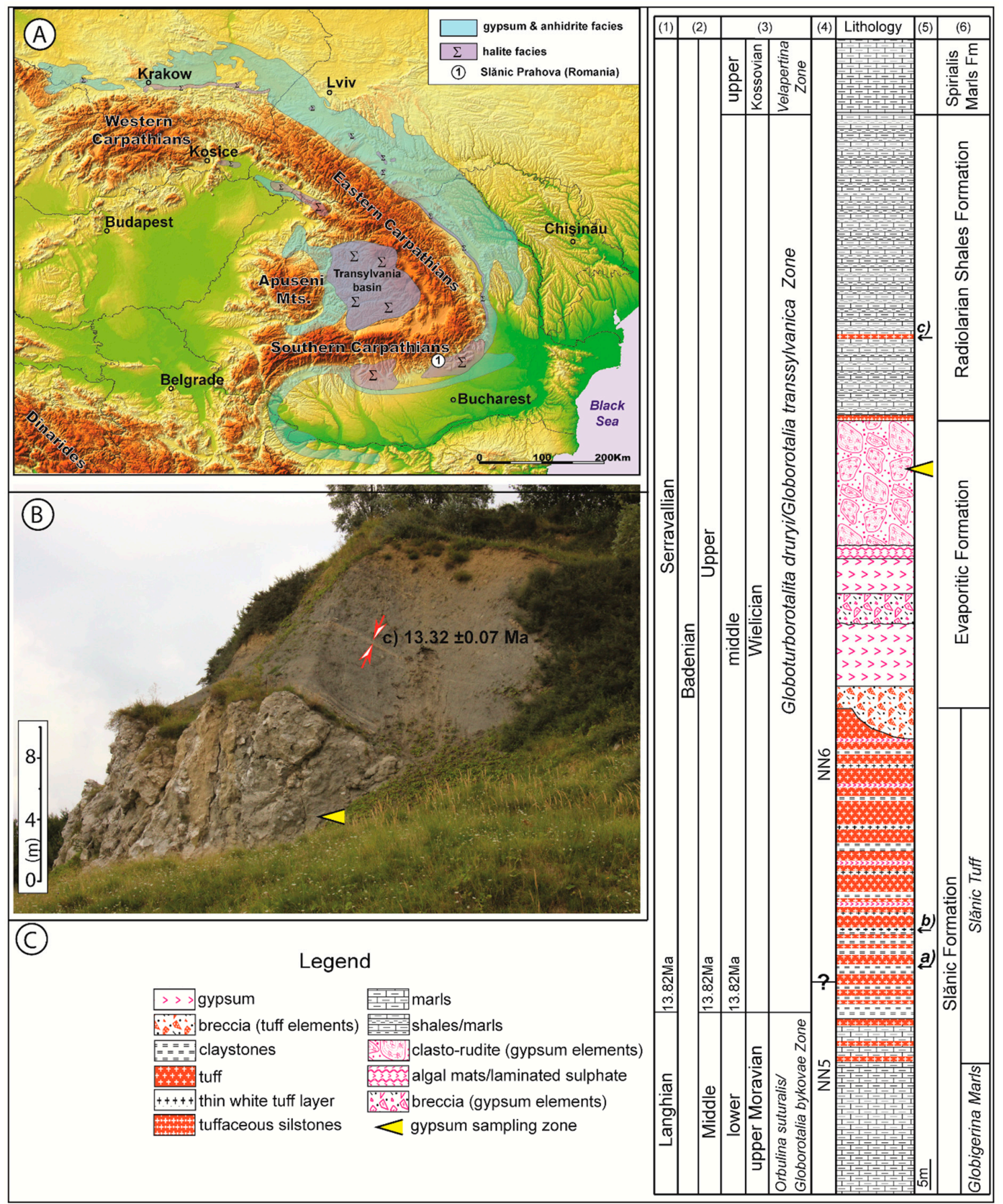

Figure 1. (A) Areal distribution of Late Badenian evaporitic deposits in the Carpathian area with the position of Slănic-Prahova locality (Piatra Verde/Green Stone; 1); (B) Photo of Piatra Verde section shows the upper part of the Evaporitic Formation (yellow arrow indicates the sample position) and Radiolarian Shales and Spirialis formations (red/white arrows indicates the position of the volcanic ash layer dated at $13.32 \pm 0.07$ Ma by [14]; (C) Lithostratigraphy at the Green Stone Hill (Muntele Piatra Verde) after [2,3,11,16]. (1) Mediterranean regional stages [17]; (2) Central Paratethys regional stages [18]; (3) Substages and Forams biozonation after [5-8] (4) Calcareous Nannoplakton Zonation [19]; (5) Events: (a) Last Common Occurrence (LCO) Sphenolithus heteromorphus [11]; (b) absolute age of a white tuff layer $13.7 \pm 0.26 \mathrm{Ma}$ [2]; (c) absolute age of a tuff layer $13.32 \pm 0.07 \mathrm{Ma}$ [14]; (6) formation names for the post-tectonic cover deposits of the Tarcău nappe. 


\section{Materials and Methods}

\subsection{Separation}

Ammonium acetate $\mathrm{NH}_{4} \mathrm{CH}_{3} \mathrm{CO}_{2}$ is a white crystalline, hygroscopic, deliquescent substance with slight vinegar like odor and can be used with acetic acid to create a buffer solution [20]. It can be formed either by the reaction of ammonia and acetic acids or of acetic acid and ammonia carbonate. It is a frequent commercial and cheap, available substance of widespread use. In addition, as a component of buffer solutions, it is used as a food additive, a precursor of drugs, in agro industries, textile industries and in various chemical processes [21]. Ammonium acetate dissolves readily in water and ethanol [20] and is easy and safe to handle. At $4{ }^{\circ} \mathrm{C}$, the solubility is $\sim 1480 \mathrm{~g} / \mathrm{L}$ [22] and the solubility increases to $\sim 5300 \mathrm{~g} / \mathrm{L}$ at $80{ }^{\circ} \mathrm{C}$. As the dissociation constants for ammonium hydroxide and acetic acid are of identical values, ammonium acetate solutions have a $\mathrm{pH}$-value of $\sim 7$, independent from concentration [23]. Therefore, carbonates are insoluble in such a solution.

In contrast, gypsum is only moderately soluble in water $\left(2.36 \mathrm{~g} / \mathrm{L}\right.$ at $\left.25^{\circ} \mathrm{C}\right)$, and it has a retrograde solubility, i.e., less soluble at higher temperatures $\left(2.09 \mathrm{~g} / \mathrm{L}\right.$ at $\left.75^{\circ} \mathrm{C}\right)$ [24].

Lead and the alkaline-earth-sulfates are readily soluble in ammonium acetate solutions. The sequence of solubility of these sulfates is: lead-calcium-strontium and barium as the lowest soluble one. Calcium sulfate shows increasing solubility with temperature and concentration. A total of $1000 \mathrm{~g}$ of a $3 \mathrm{~N}$ ammonium acetate solution at a temperature of $25^{\circ} \mathrm{C}$ (corresponding to a concentration of $\sim 231 \mathrm{~g} / \mathrm{L}$ ) dissolves $\sim 26 \mathrm{~g}$ calcium sulfate [25]. As the solubility of ammonium acetate in water at $80^{\circ} \mathrm{C}$ is $\sim 5300 \mathrm{~g} / \mathrm{L}$ and the solubility of calcium sulfate in ammonium acetate solution is increasing with the concentration, the maximum of dissolved calcium sulfate is by potencies higher as $26 \mathrm{~g} / \mathrm{kg}$ solution for such concentrations.

The sample prepared for this study belongs to the upper part of the Evaporitic Formation (Figure 1B). To gain microfossil remains of gypsum rich rocks of the Muntele Piatra Verde sequence, Slănic Prahova, Romania, a representative gypsum rich sample (MV19) of $100 \mathrm{~g}$ was crushed in a jaw crusher and wet sieved for the fractions 63, 150, 250, 425 and $850 \mu \mathrm{m}$. To avoid precipitation of large amounts of salt during cooling down of a supersaturated solution, the experiment was started at room temperature and the associated maximum solubility of ammonium acetate. As the solubility of ammonium acetate is $\sim 1500 \mathrm{~g} / \mathrm{L}$ at $20^{\circ} \mathrm{C}, 750 \mathrm{~g}$ of ammonium acetate was dissolved in $500 \mathrm{~mL}$ deionized water at room temperature in a glass beaker by mixing with a magnetic stirrer. The resulting solution with a volume of $1.2 \mathrm{~L}$, i.e., has a concentration of $\sim 8 \mathrm{~N}$. It is not recommendable to heat this solution directly on a heating plate as, within a short time, a precipitate is formed. Stirring the beaker is also not recommendable because of the fragility of the fossils. Therefore, the solution was filled in a wide neck bottle, a sieved fraction was added and the bottle was closed with a ground glass stopper. The bottle was placed in a compartment dryer at $80^{\circ} \mathrm{C}$ for about $12 \mathrm{~h}$. Possible gelatinous masses on the bottom of the bottle are a mixture of disaggregated fine-grained particles of the sample and precipitate from the solution. Both precipitate and undissolved sample were checked by powder XRD. No remaining gypsum was detected neither in the undissolved fraction of the sample nor in the precipitate. Main phases of the precipitate are Ca-acetate and a non-identified phase. Luckily, both phases are readily water-soluble. The remaining ammonium acetate solution was decanted and the bottle was refilled with deionized water and placed again at $80{ }^{\circ} \mathrm{C}$ in the compartment dryer for $\sim 1 \mathrm{~h}$. Decanting and refilling was repeated once. The residue was spilled in a small beaker and again filled up with deionized water and treated with an ultrasonic cleaner to get rid of remaining fine particles. The cleaned sample was finally dried in the compartment dryer at $40^{\circ} \mathrm{C}$ and afterward checked under the microscope and handpicked for final concentration and determination.

\subsection{XRD Measurements}

X-ray diffraction patterns of the sample before and after the treatment with acetate were measured on a Bruker AXS D8 diffractometer equipped with a one-dimensional strip-detector (lynx-eye) using a 
$\mathrm{Cu}-\mathrm{k} \alpha\left(40 \mathrm{kV}, 40 \mathrm{~mA}\right.$, sample rotation). The measuring conditions were: step-size $0.02^{\circ}, 2 \mathrm{sec} / \mathrm{step}$ (equivalent to $304 \mathrm{sec} /$ steps with a conventional point-detector). Mineralogical compositions of samples before and after the treatment with ammonium acetate are given in Figure 2A,B.
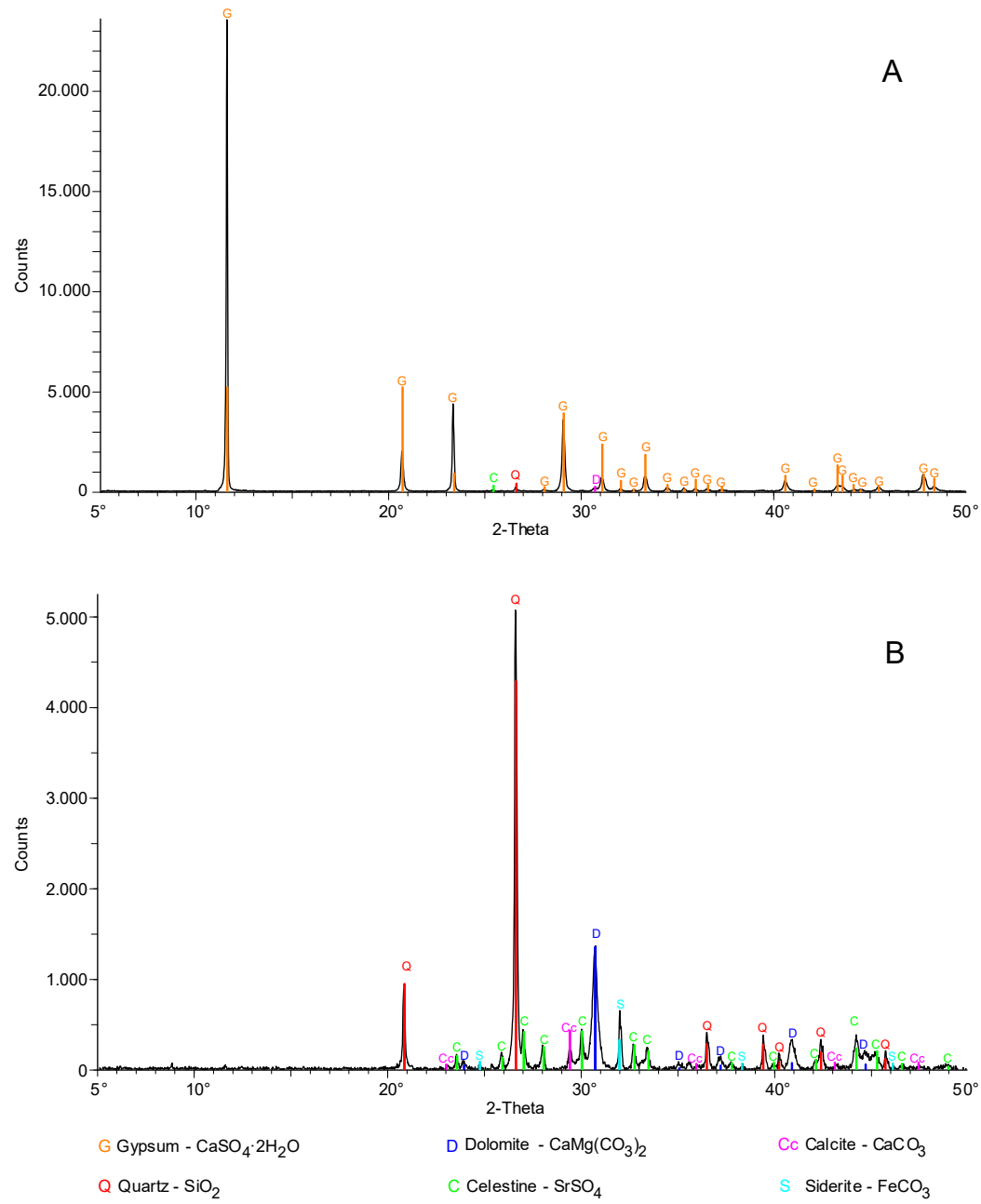

Figure 2. (A) Mineralogical composition of sample before dissolution, XRD determination; (B) mineralogical composition of sample after dissolution with ammonium acetate.

\subsection{Carbonate Content}

Before dissolution with ammonium acetate, we determined the carbonate content of the sample with a Scheibler calcimeter. A part of the sample was crushed and ca. $1 \mathrm{~g}$ was placed in the Scheibler apparatus. The sample was treated with a $10 \% \mathrm{HCl}$ solution and the resulting $\mathrm{CO}_{2}$ was volumetric quantified. The calculation of the carbonate content includes air pressure and temperature corrections.

\subsection{Foraminifer Images}

The determined foraminifers are displayed in Figures 3-6. 


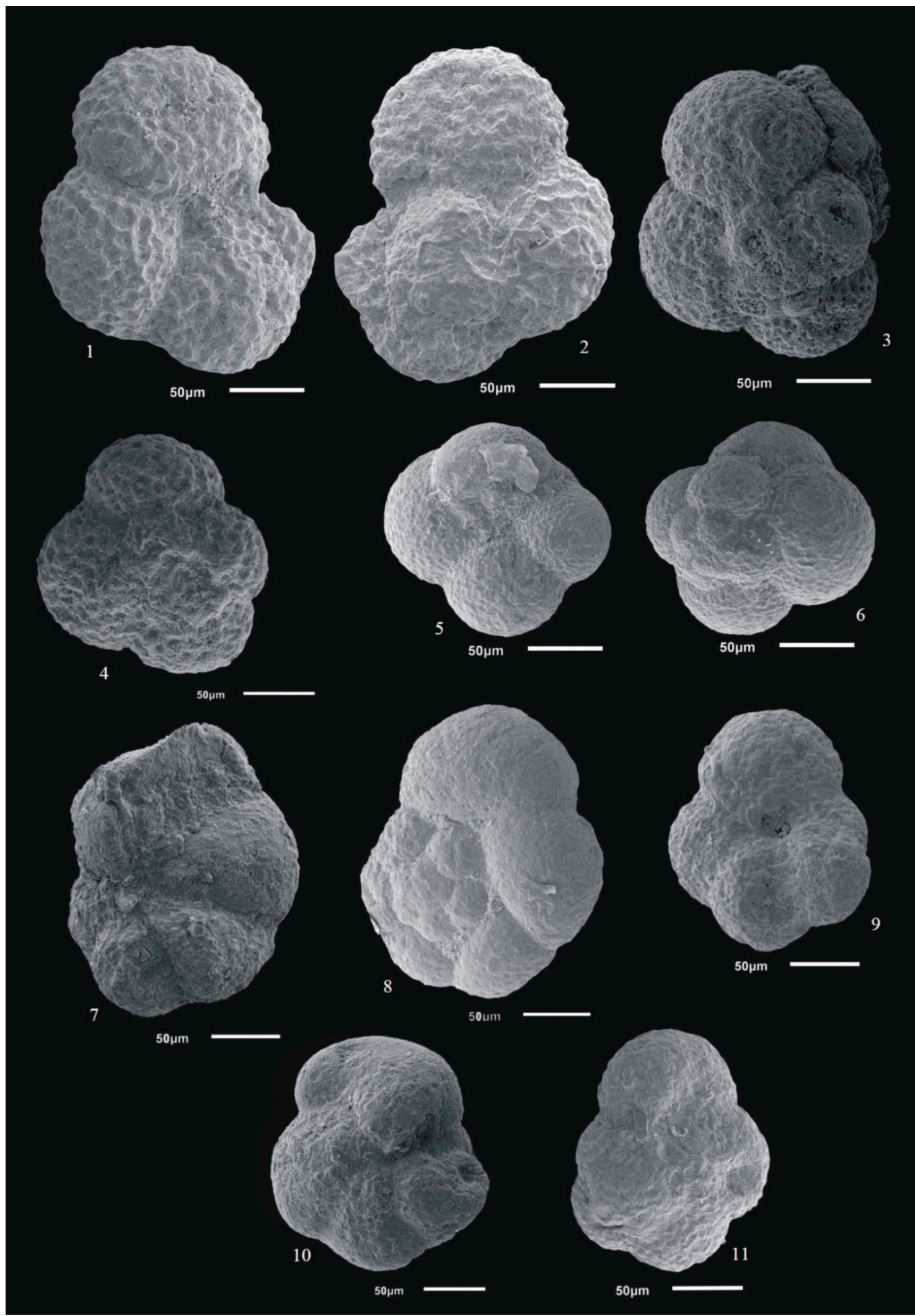

Figure 3. Planktonic foraminifera identified in the gypsum sample (SEM pictures): (1-4). Globigerina bulloides d'Orbigny; $(5,6)$. Globigerina bollii Cita \& Premoli-Silva; $(7,8)$. Globorotalia transsylvanica Popescu; Paragoborotalia sp.; $(9,11)$. Tenuitella angustiumbilicata (Bolii); (10). Globorotalia praescitula Blow. 


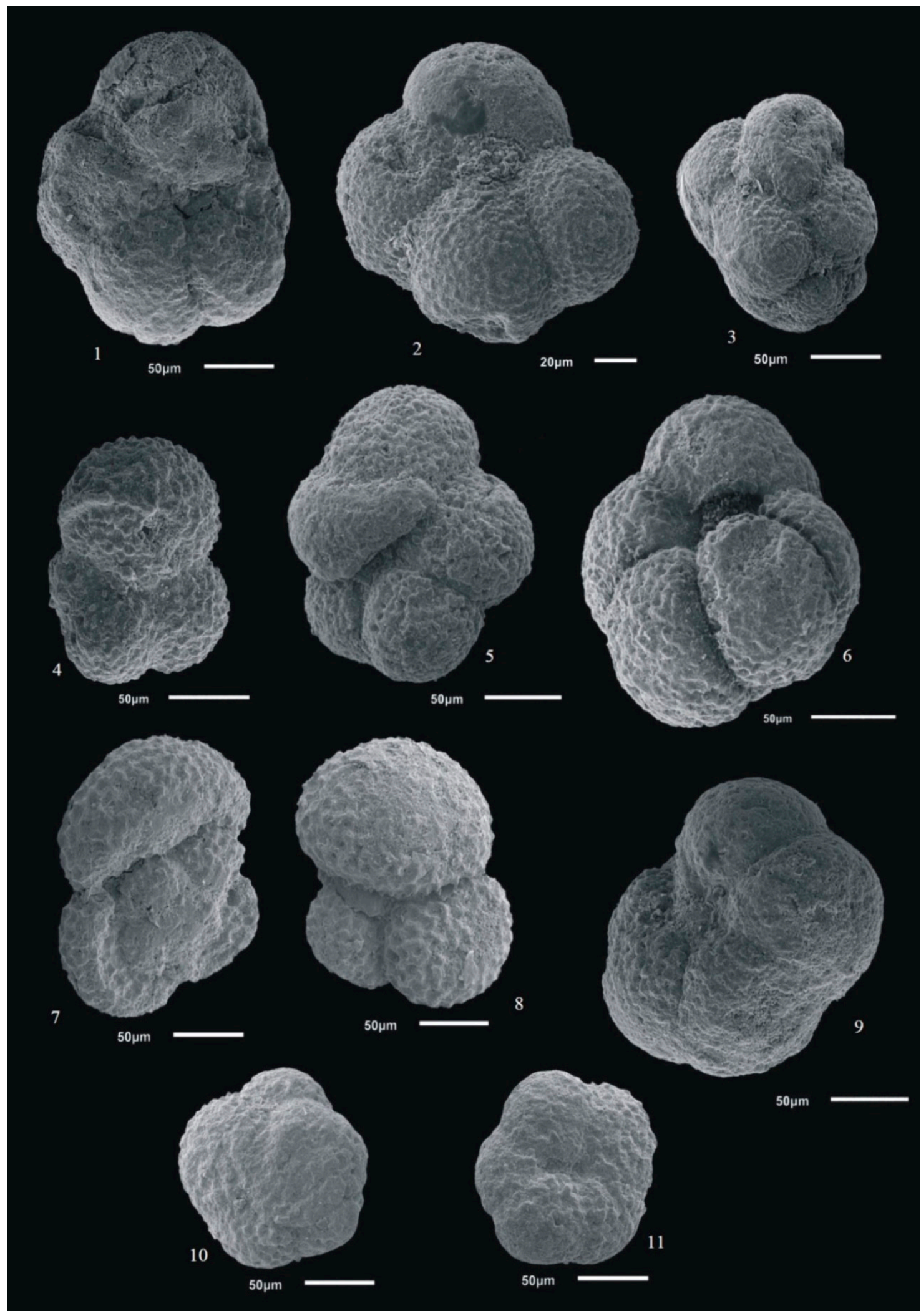

Figure 4. Planktonic foraminifera identified in the gypsum sample (SEM photos, continuation): (1). Tenuitella angustiumbilicata (Bolii); (2). Globigerinita aff. glutinata (Egger); (3). Globigerinita uvula (Ehrenberg); (4). ?Globigerina praebulloides Blow; (5). Globigerina sp. (with bullae); (6). Globorotalia sp.1; $(7,8)$. Globigerinoides sp.; (9); Globorotalia sp.2; $(10,11)$; Paragloborotalia sp. 1. 


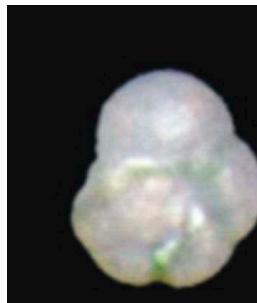

1

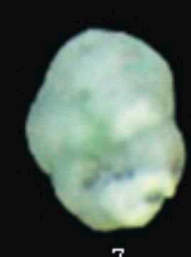

7

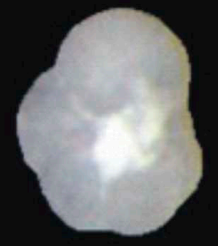

2

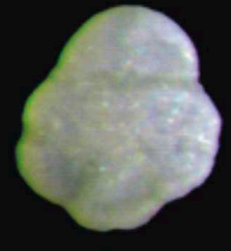

3

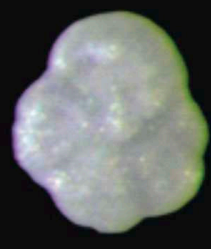

4

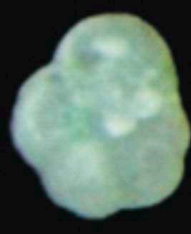

5

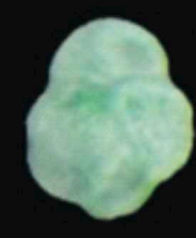

6
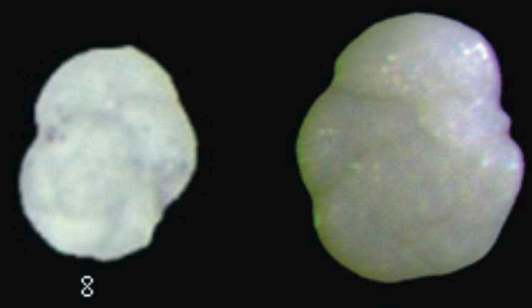

9

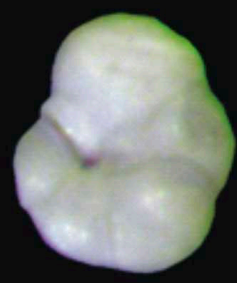

10

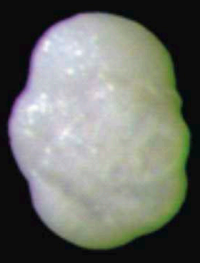

11

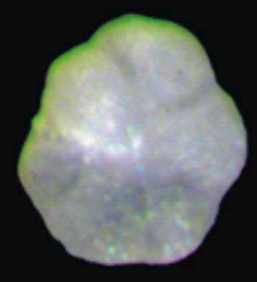

12

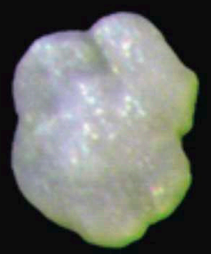

13

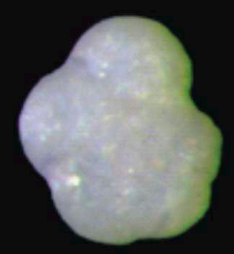

14

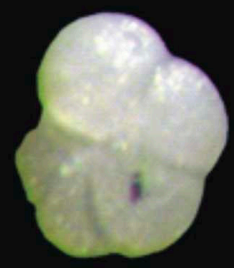

15

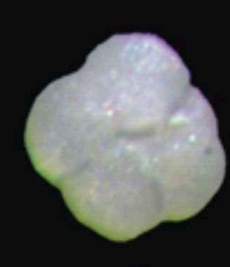

16

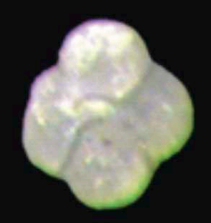

17

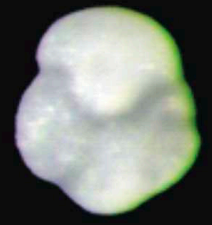

18

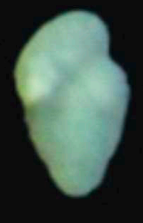

19

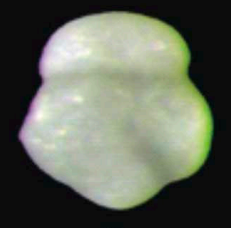

20

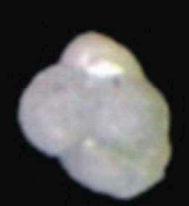

21

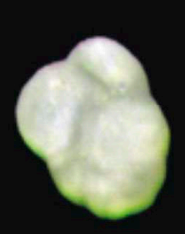

22

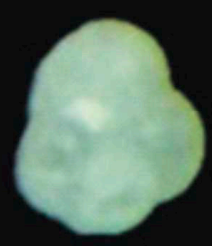

23

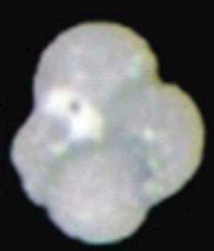

24

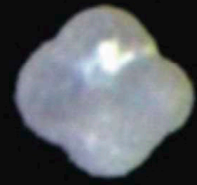

25

Figure 5. Planktonic foraminifera identified in the gypsum sample (digital photos): (1,2). Paragloborotalia sp. 2; (7,8). Paragloborotalia sp.3; Globorotalia bykovae Aisenstat; (9-12). Globorotalia transylvanica Popescu; (13). Globorotalia sp. 3; $(14,15)$. Globorotalia transylvanica Popescu; (16). Tenuitella angustiumbilicata (Bolii); (17). Globigerina sp.; (18-20). Globorotalia praescitula Blow; $(21,22)$. Globigerinita uvula (Ehrenberg); (23). Globoturborotalita aff. woodi (Jenkins); (24). Globigerina praebulloides Blow; (25). Globigerina bollii Cita \& Premoli-Silva. 


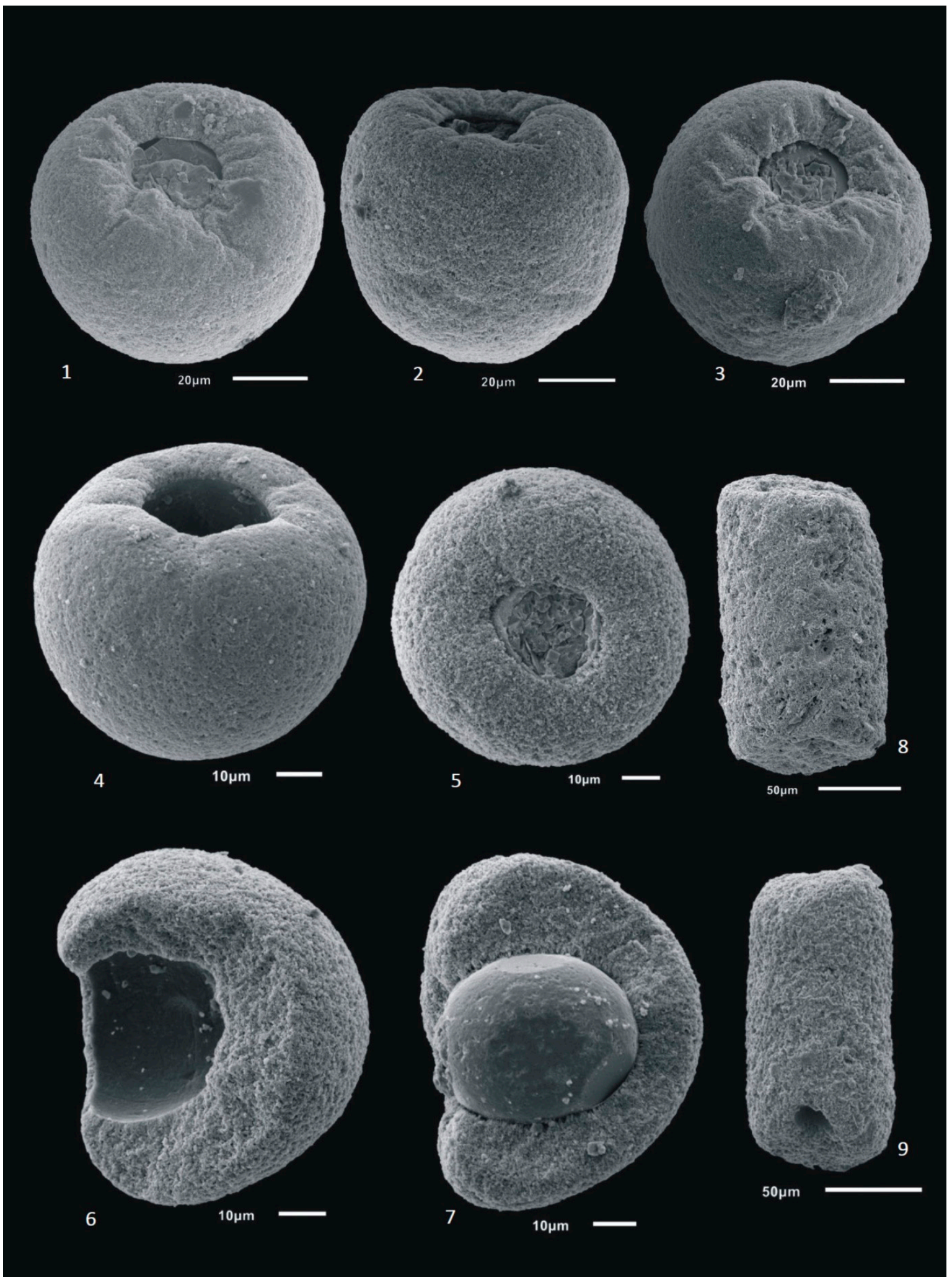

Figure 6. Algae cysts identified in the gypsum sample: (1-7). Cysts of Halicoryne morelleti (Pokorny); $(8,9)$-possible algae fragments.

For Figures 3, 4 and 6, scanning electron microscope (SEM) secondary electron images were done with a tungsten filament Jeol 6610LV microscope in the high vacuum mode. Fossil remains were 
placed on an aluminum pin mount with a carbon adhesive tab, and the samples were gold sputtered. Operating conditions were $10 \mathrm{kV}$ with a working distance of $10 \mathrm{~mm}$.

For Figure 5, we also used digital pictures taken with a Zeiss Stemi SV11 microscope with a Nikon digital camera adapted to it.

\section{Results and Discussion}

In Figure 2A, XRD-powder analysis of the bulk rock sample shows the presence of gypsum with minor amounts of quartz, dolomite and celestine. Calcite is diluted below the detection limit of the method. As determined with the Scheibler apparatus, the total carbonate content of the sample is 3.51 weight $\%$ (average of two analyses 3.48 and $3.54 \mathrm{wt} . \%$ ). After gypsum dissolution with acetate, in the residuum, quartz, dolomite, siderite, celestine and calcite were detected in the fraction 63-150 micron, which hosted most of the fossil remnants (Figure 2B). Moreover, using the experimental data, namely the Scheibler measurement on total carbonate before dissolution as well as the partitioning between carbonates obtained by XRD after dissolution, it is possible to calculate a rough estimation of the fraction of various carbonates in the bulk sample. Accordingly, the content of calcite, dolomite and siderite was performed from the main peak areas (at 3.03, 2.89 and $2.80 \AA$ ): $\sim 5 \%$ calcite, $\sim 80 \%$ dolomite and $\sim 15 \%$ siderite, which corresponds to calcite content in the bulk sample MV19 before dissolution of $\sim 0.2$ weight \%. These quantitative estimations show how efficient the present method is, allowing final concentration of foraminifera from a bulk sample with trace calcite content.

The planktonic foraminifera assemblage determined in washed residuum is characterized by small-sized individuals, as indicated in Figures 3-5. The following foraminifera species have been identified: Globoturborotalita aff. woodi (Jenkins), Globorotalia bykovae Aisenstat, Globorotalia transsylvanica Popescu, Globorotalia praescitula Blow, Globigerinita uvula (Ehrenberg), Globigerina bulloides d'Orbigny, Globigerina praebulloides Blow, Globigerina bollii Cita \& Premoli-Silva, Tenuitella angustiumbilicata (Bolii), Globigerinita aff. glutinata (Egger), Globigerina sp., Globigerinoides sp., Globorotalia sp.1, Globorotalia sp 2, Paragloborotalia sp. 1, Paragloborotalia sp. 2 and Paragloborotalia sp. 3. For some of the identified species, the interval of occurrence within the Badenian regional stage is given in Table 1. This microfossil association contains planktonic taxa with a wide stratigraphic range. Few species are stratigraphically more restricted, being very abundant in the Langhian (Moravian) deposits [8,26,27].

In the Paratethys, Globoturborotalita woodi (Jenkins) occurs only in Moravian and Wielician (Early and Middle Badenian/Langhian-base Serravalian) [8] and Globorotalia bykovae Aisenstat has a more restricted stratigraphic range, abundant in Moravian (Langhian) [8,26]. Also, Globigerina bolii Cita and Premoli-Silva has a restrictive stratigraphic range that covers the Karpatian (uppermost Burdigalian)-base Moravian (base Langhian) interval time [28]. 
Table 1. Stratigraphic range of the foraminifera species identified in the gypsum samples, ranges based on $[8,26,29]$.

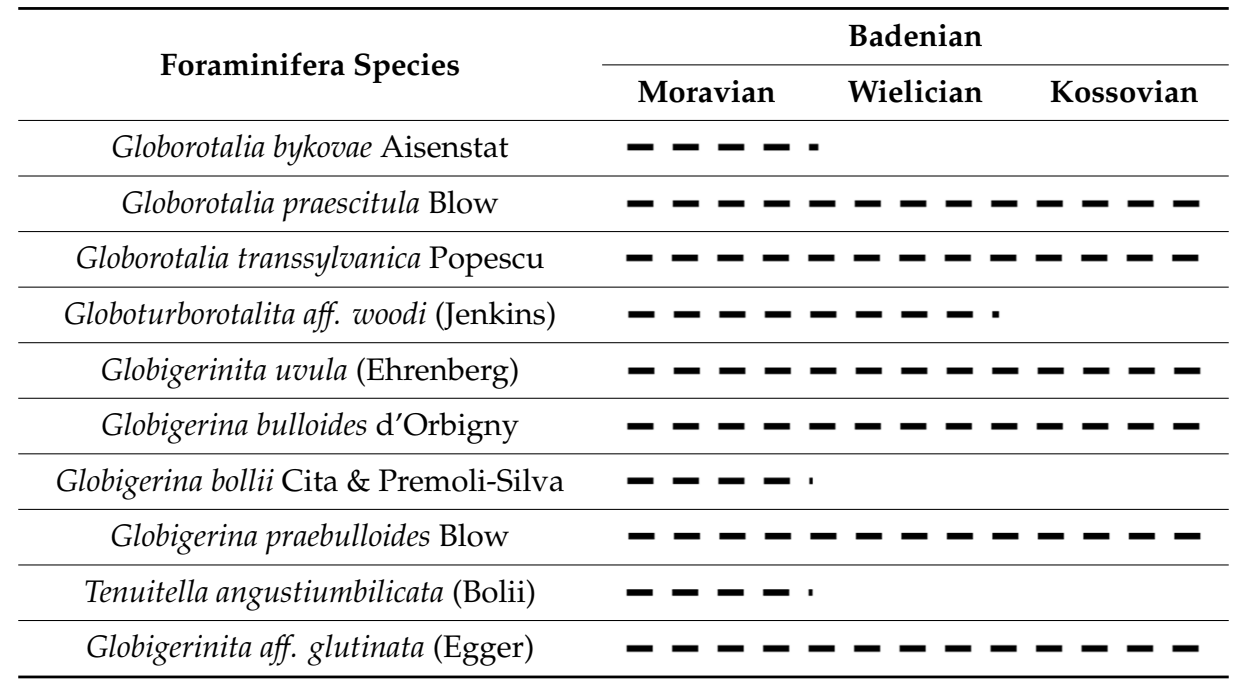

The endemic species Globorotalia transsylvanica Popescu occurs from the Karpatian (Late Burdigalian) up to Kossovian (Late Badenian/Early Serravalian) [29], being common in Wielician/Middle Badenian [8].

In the identified planktonic foraminifera assemblage, some of the species have a larger interval of occurrence, as given in Table 1 and below: Globorotalia prescitula Blow, Lower to Middle Miocene [8], Lower Miocene (Burdigalian) to Middle Miocene (Serravalian) [30]; Globigerinita uvula (Ehrenberg), first occurrence in late Oligocene [31]; Tenuitella angustiumbilicata (Bolii), first occurrence in Lower Oligocene and the last occurrence in Lower Burdigalian [31] but also mentioned in Moravian/Langhian [29]. Globigerinita glutinata (Egger) occurs from the Lower Oligocene to present [32]. Also, Globigerina bulloides d'Orbigny and Globigerina praebulloides Blow had first occurrences in Upper Oligocene to present [32]. For Tenuitella angustiumbilicata (Bolii) and Globigerinita uvula (Ehrenberg), as there are several synonyms, we used the latest nomenclature indicated by [31] and [28], respectively.

The identified foraminifera assemblage shows similarities with the planktonic foraminifera assemblages mentioned from Slănic Formation by $[9,10]$. A similar occurrence of small planktonic foraminifera has been mentioned just below the gypsum deposition in NW Transylvanian Basin, indicating clear paleoenvironmental changes toward more cold waters [27]. During the Messinian stage, increasing abundance of small planktonic foraminifers in clays, before deposition of evaporates, were described by [33]. Taking into consideration that the gypsum deposition corresponds to a saline episode, in which marine connections are progressively closed and the water level dropped, we suggest that the identified planktonic foraminiferal assemblage is reworked or represents inputs of fresh water from less saline environments surrounding the lagoon where gypsum deposited. In this context, the ecological factor responsible for the small forms may be a combination of factors, such as cold water at the time of gypsum deposition and or oligotrophic conditions.

In the microfossil assemblage, cysts of Halicoryne morelleti (Pokorny), a green algae, were also identified (Figure 6). Most cysts have a spherical shape, sometimes they are ovoid. They have no contact traces, which could indicate that they were separated during life. This type of algae is usually associated with microfossils of the Sarmatian age [34,35]. In only one area from Romania (Costei locality), these algae are mentioned for Badenian deposits [36]. In Poland, green algae assigned to Halicoryne cf. morelleti (Pokorny) are found together with marine shallow-water ostracod fauna indicating the Badenian age [37]. These green algae lived in marine environments, mainly shallow (up to $30 \mathrm{~m}$ depth), with normal salinity and subtropical-tropical waters [37,38], but they could adapt to lower salinity conditions [34]. They lived in low turbulence environments typical for coastal lagoons. 


\section{Conclusions}

Ammonium acetate is a substance with a low chemical hazard. Treatment of gypsum rich rocks for fossil preparation with ammonium acetate solution is therefore easy to handle, fast and a low-cost method. No additional devices are necessary besides the standard equipment of a chemical laboratory. Using this method, micropaleontological studies of sedimentary sequences may be extended to the gypsum rich layers.

For the first time, we determined a foraminiferal association exclusively made of small sized planktonic species. The microfossil assemblage is represented by a mixed association of warm to cold water species, presenting similarities with the planktonic foraminifera assemblages mentioned for Slănic Formation. Green algae cysts were identified as well. No benthonic foraminifers have been found.

Author Contributions: Investigation, C.A.; methodology, H.-P.B.; software, V.B.; visualization, C.A. and V.B.; writing—original draft, A.-V.B.; writing—review and editing, H.-P.B. and A.-V.B. All authors have read and agreed to the published version of the manuscript

Funding: This research received no external funding.

Acknowledgments: We thank two anonymous reviewers for interesting suggestions and comments which helped to improve the manuscript.

Conflicts of Interest: The authors declare no conflict of interest.

\section{References}

1. Hardie, L.A. Secular variation in seawater chemistry: An explanation for the coupled 500 secular variation in the mineralogies of marine limestones and potash evaporites over the past 600 m.y. Geology 1996, 24, 279-283. [CrossRef]

2. Bojar, A.-V.; Barbu, V.; Wojtowicz, A.; Bojar, H.-P.; Hałas, S.; Deliu, O.G. Miocene Slănic Tuff, Eastern Carpathians, Romania, in the Context of Badenian Salinity Crisis. Geoscience 2018, 8, 73. [CrossRef]

3. Frunzescu, D. Miocene from Southern Part of Eastern Carpathians-Sulphate Evaporitic Mega-Sequence; Editura Universităţii Petrol-Gaze din Ploieşti: Ploieşti, Romania, 2013; 344p, ISBN 978-973-719-518-0.

4. Dumitrică, P.; Gheta, N.; Popescu, G.H. Date noi cu privire la biostratigrafia si corelarea Miocenului mediu din aria carpatica. Dări De Seamă Ale Sedinţelor Inst. De Geol. Şi Geofiz. 1975, 61, 65-81.

5. Crihan, I.M. Middle Miocene Litho- and Biostratigraphical Study between Prahova Valley and Teleajen Valley, at Southern Part of the Slănic Syncline. Ph.D. Thesis, Babeş-Bolyai University, Cluj-Napoca, Romania, 1999.

6. Popescu, G.H. Lower and Middle Miocene Agglutinated Foraminifera from the Carpathian Area. Acta Palaeontol. Rom. 1999, 2, 407-425.

7. Popescu, G. Marine Middle Miocene microbiostratigraphical correlation in Central Paratethys. Dări Seamă Ale Sedinţelor Inst. Geol. Şi Geofiz. 1987, 72, 149-168.

8. Popescu, G.; Crihan, I.M. Middle Miocene Globigerinas of Romania. Acta Palaeontol. Rom. 2011, 7, $291-314$.

9. Crihan, M. Palaeoecology of the Badenian foraminifera between the Prahova Valley and Teleajen Valley (Subcarpathians of Muntenia). In Proceedings of the XVII Congress of Carpathian-Balkan Geological Association, Bratislava, Slovakia, 1-4 September 2002.

10. Stoica, M.; Andrăşanu, A.; Palcu, D.; Popa, R.G. The Miocene from Buzău Area. A Geological and Geoconservation Perspective; Editura Universităţii din Bucureşti: București, Romania, 2017; 44p, ISBN 978-606-16-0913-0.

11. Melinte-Dobrinescu, M.C.; Stoica, M. Badenian calcareous nannofossil fluctuation in the Eastern Carpathians: Palaeoenvironmental significance. Acta Palaeontol. Rom. 2014, 9, 47-57.

12. Popescu, G. Observaţii asupra breciei sării şi a unor masive de sare din regiunea paleogen-miocenă a judeţului Prahova. Dări Seamă Ale Inst. Geol. 1951, 32, 3-13.

13. De Leeuw, A.; Bukowski, K.; Krijgsman, W.; Kuiper, K.F.; Stoica, M.; Tulbure, M. Chronology of the Badenian Salinity Crisis of the Central Paratethys. In Proceedings of the Paratethys-Mediterranean Interactions: Environmental Crises during the Neogene, Abstract volume RCMNS Colloqium, Bucharest, Romania, 27-28 September 2012. 
14. De Leeuw, A.; Tulbure, M.; Kuiper, K.F.; Melinte-Dobrinescu, M.C.; Stoica, M.; Krijsman, W. New ${ }^{40} \mathrm{Ar} /{ }^{39} \mathrm{Ar}$, magnetostratigraphic and biostratigraphic constrains on the termination on the Badenian Salinity Crisis: Indications for tectonic improvement of basin interconnectivity in Southern Europe. Glob. Planet. Chang. 2018, 169, 1-55. [CrossRef]

15. Mărunţeanu, M. Litho- and biostratigraphy (calcareous nannoplankton) of the Miocene deposits from the Outer Moldavides. Geol. Carpath. 1999, 50, 313-324.

16. Frunzescu, D. Miocene evaporites from the southern part of Eastern Carpathians-Sedimentological approach. Rom. J. Miner. Depos. 2010, 85, 23-30.

17. Hilgen, F.; Lourens, L.J.; van Dam, J.A. The Neogene period. In The Time Geologic Scale 2012; Gradstein, F.M., Ogg, J.G., Schmitz, M.A., Ogg, G.M., Eds.; Elsevier: Amsterdam, The Netherlands, 2012; pp. 1083-1127. ISBN 978-0-444-59425-9.

18. Hohenegger, J.; Ćorić, S.; Wagreich, M. Timing of the Middle Miocene Badenian Stage of the Central Paratethys. Geol. Carpath. 2014, 65, 55-66. [CrossRef]

19. Martini, E. Standard Tertiary and Quaternary calcareous nannoplankton zonation. In Proceedings of the 2nd Planktonic Conference 1970, Roma, Italy, 1970.

20. Liu, J. Ammonium Acetate. Encyclopedia of Reagents for Organic Synthesis; John Wiley \& Sons, Ltd.: Hoboken, NJ, USA, 2017; pp. 1-2.

21. Barthakur, M.G. Ammonium Acetate. Synlett 2007, 9, 1475-1476. [CrossRef]

22. Falbe, J.; Regitz, M. Ammoniumacetat, Römmp Lexikon der Chemie Band 1: A-Cl; Thieme: Stuttgart, Germany, 1996; 780p.

23. Williams, R.J.; Lyman, C.M. A Neutral Buffered Standard for Hydrogen Ion Work and Accurate Titrations Which Can be Prepared in One Minute. J. Am. Chem. Soc. 1932, 54, 1911-1912. [CrossRef]

24. Hulett, G.A.; Allen, L.E. The solubility of Gypsum. J. Am. Chem. Soc. 1902, 24, 667-679. [CrossRef]

25. Marden, J.W. Solubilities of the Sulfates of Barium, Strontium, Calcium, and Lead in Ammonium Acetate Solutions at $25^{\circ}$ and a Criticism of the Present Methods for the Separation of These Substances by Means of Ammonium Acetate Solution. J. Am. Chem. Soc. 1916, 38, 310-316. [CrossRef]

26. Popescu, G. Etudes des foraminiferes du Miocene inferieur et moyen du Nord-Ouest de la Transylvanie. Memoires 1975, 23, 121.

27. Filipescu, R.; Filipescu, S. New data on the Early-Middle Badenian transition in the NW Transylvanian Basin (Romania) reveald by planktonic foraminifera assemblages. Studia Ubb Geol. 2014, 59, 39-44. [CrossRef]

28. Iaccarino, S.M.; Premoli, S.; Biolzi, M.; Foresi, L.M.; Lirer, F.; Turco, E.; Petrizzo, M.R. Practical Manual of Neogene Planktonic Foraminifera; International School of Planktonic Foraminifera, Universita degli Studi di Milano, Dipartimento di Scienze della Terra “Ardito Desio": Milano, Italy, 2007; 143p.

29. Cicha, I.; Rögl, F.; Rupp, C.; Ctyroká, J. Oligocene-Miocene foraminifera of the Central Paratethys. Abh. Der Senckenbergischen Nat. Ges. 1998, 549, 1-325.

30. Wade, B.S.; Pearson, P.N.; Berggren, W.A.; Pälike, H. Review and revision of Cenozoic tropical planktonic foraminiferal biostratigraphy and calibration to the geomagnetic polarity and astronomical time scale. Earth-Sci. Rev. 2011, 104, 111-142. [CrossRef]

31. Pearson, P.N.; Bridget, S.; Wade, B.S.; Huber, B.T. Taxonomy, biostratigraphy, and phylogeny of Oligocene Globigerinitidae (Dipsidripella, Globigerinita, and Tenuitella). In Atlas of Oligocene Planktonic Foraminifera; Wade, B.S., Olsson, R.K., Pearson, P.N., Huber, B.T., Berggren, W.A., Eds.; Cushman Foundation for Foraminiferal Research: Lawrence, KS, USA, 2018; Chapter 16; pp. 429-458.

32. Spezzaferri, S.; Coxall, H.K.; Olsson, R.K.; Hemleben, C. Taxonomy, biostratigraphy, and phylogeny of Oligocene Globigerina, Globigerinella, and Quiltyella n. gen. In Atlas of Oligocene Planktonic Foraminifera; Wade, B.S., Olsson, R.K., Pearson, P.N., Huber, B.T., Berggren, W.A., Eds.; Cushman Foundation for Foraminiferal Research: Lawrence, KS, USA, 2018; Chapter 6; pp. 179-214.

33. Violanti, C.; Donata, V.; Lozar, F.; Natalicchio, M.; Dela Pierre, F.; Bernardi, E.; Clari, P.; Cavagna, S. Stress-tolerant microfossils of a Messinian succession from the Northern Mediterranean basin (Pollenzo section, Piedmont, northwestern Italy). Boll. Della Soc. Paleontol. Ital. 2013, 52, 45-54.

34. Bucur, I.I.; Nicorici, E.; Surar, N. Sarmatian Calcareous Algae from Rumania; Mucchi: Mondena, Italy, 1993; pp. 81-91.

35. Barattolo, F.; Ionesi, V.; Tibulea, P. A new polyshysacean alga from the Miocene of Romania and its biomineralization. Acta Palaeontol. Pol. 2019, 64, 85-100. [CrossRef] 
36. Rado, G. Dasycladacee in Tortonian deposits from R.S. Romania. Anal. Univ. Buc. Geol. Geogr. 1966, 15, 61-66.

37. Szczechura, J. Middle Miocene (Badenian) ostracods and green algae (Chlorophyta) from Kamienica Nawojowska, Nowy Sacz Basin (Western Carpathians, Poland). Geol. Carpath. 2006, 57, 103-122.

38. Paruch-Kulczycha, J. Algae in the Sarmatian deposits from the Machow outcrop and from the boreholes Jamnica M-83 and S-119 (Carpathian Foredeep). Geol. Q. 1994, 38, 571-576.

(C) 2020 by the authors. Licensee MDPI, Basel, Switzerland. This article is an open access article distributed under the terms and conditions of the Creative Commons Attribution (CC BY) license (http://creativecommons.org/licenses/by/4.0/). 